Revue bibliographique pour le domaine irano-aryen

Volume 40-41 | 2019

Comptes rendus des publications de 2017-2018

\title{
Rolf Strootman, Miguel John Versluys (eds.). Persianism in Antiquity
}

\section{Florence Somer}

\section{(2) OpenEdition \\ 1 Journals}

\section{Édition électronique}

URL : http://journals.openedition.org/abstractairanica/49856

DOI : 10.4000/abstractairanica.49856

ISBN : 1961-960X

ISSN : 1961-960X

Éditeur :

CNRS (UMR 7528 Mondes iraniens et indiens), Éditions de l'IFRI

Référence électronique

Florence Somer, «Rolf Strootman, Miguel John Versluys (eds.). Persianism in Antiquity », Abstracta

Iranica [En ligne], Volume 40-41 | 2019, document 16, mis en ligne le 30 décembre 2019, consulté le 27 avril 2021. URL : http://journals.openedition.org/abstractairanica/49856 ; DOI : https://doi.org/ 10.4000/abstractairanica.49856

Ce document a été généré automatiquement le 27 avril 2021

Tous droits réservés 


\title{
Rolf Strootman, Miguel John Versluys (eds.). Persianism in Antiquity
}

\author{
Florence Somer
}

\section{RÉFÉRENCE}

Rolf Strootman, Miguel John Versluys (eds.). Persianism in Antiquity. Stuttgart : Franz Steiner, 2017, p. (Oriens et Occidens 25)

1 Ce volume est issu en grande partie des actes d'un colloque consacré à la mémoire culturelle et politique de l'Empire achéménide dans l'Antiquité. Il vise à permettre une appréhension interdisciplinaire de la conception de "persianisme ", de l'Antiquité à nos jours. Le volume se divise en trois parties : "Persanisation, Persomanie, Perserie », «Le monde hellénistique ", "Perspectives romaines et sassanides ». Cette dernière partie occupe une place importante dans le volume. La confrontation des idées sousjacentes au concept de «persianisme » dans les différentes contrées non iraniennes, qu'elles soient limitrophes du cœur de l'empire ou à la périphérie des provinces perses, montre la diversité du modèle culturel (centré notamment sur l'autorité, les mythes ou le banquet persan) tel qu'il était perçu de l'extérieur. Archétype adopté par les élites des différents voisins de l'Iran durant l'Antiquité, le «persianisme » a également servi une idéologie populaire. La récupération des motifs politiques et culturels persans ainsi que leur appropriation par les dirigeants à différentes périodes de l'histoire avait également pour effet majeur de recentrer les Iraniens autour d'une identité nationaliste forte, idéologique et technologiquement supérieure.

Plusieurs articles de ce volume font l'objet d'un abstract séparé/particulier. 


\section{AUTEURS}

\section{FLORENCE SOMER}

Doctorante EPHE, Mondes iranien et indien, Paris 